\title{
DIALOGUES ON TRANSLINGUAL RESEARCH AND PRACTICE: WEAVING THREADS WITH SURESH CANAGARAJAH' ${ }^{1}$ S VIEWS
}

\author{
Diálogos sobre prática e pesquisa translíngues: entrelaçando visões com \\ Suresh Canagarajah
}

\author{
Ruberval Franco MACIEL \\ Universidade Estadual do Mato Grosso do Sul \\ ruberval.maciel@gmail.com \\ https://orcid.org/0000-0003-0373-1047
}

Cláudia Hilsdorf ROCHA

Universidade Estadual de Campinas claudiahrocha@gmail.com https://orcid.org/0000-0001-9717-2375

\begin{abstract}
The main purpose of this paper is to engage with the ideas of Suresh Canagarajah - a highly acknowledged scholar from Penn State University, in the United States of America - on translingual research and practice. In order to do so, an interview with him was jointly planned by Ruberval Franco Maciel (UEMS) and Cláudia Hilsdorf Rocha (UNICAMP) and carried out in August 2019, during an event held in Brazil. Taking into account the increasing number of studies on translingualism worldwide in the past few years and the leading role played by Canagarajah's work in this field, the interview aimed at expanding views and contributing to broaden the scholarship in this area. To situate and contextualize the author's ideas, some considerations on translanguaging as a language theory and educational approach are firstly made. As a result, Canagarajah's voice and points of view are put in dialogue with a plurality of ideas, highlighting the complex, dynamic and challenging nature of a translingual turn in contemporary times and its possible connections with Brazilian language studies. Translingual work intertwined with affective, multimodal and multisensory approaches is considered a possible and interesting path to be explored in the near future.
\end{abstract}

\footnotetext{
${ }^{1}$ Suresh Canagarajah is Edwin Erle Sparks Professor of Applied Linguistics, English, and Asian Studies at Penn State University. He is a distinguished author in the fields of translanguaging, translingualism, linguistic imperialism and social and political issues in language education. His Translingual Practice: Global Englishes and Cosmopolitan Relations (Routledge, 2013) won the best book awards from American Association of Applied Linguistics, British Association of Applied Linguistics, and the Modern Language Association of America. He is a former editor of TESOL Quarterly and President of the American Association of Applied Linguistics. His profile can be visited at: <http://www.personal.psu.edu/asc16/> .
} 
KEYWORDS: Translingual research and practice; Translanguaging Education; Affect; Multimodal lens; Multisensory approach.

RESUMO: O propósito central deste manuscrito é apresentar as ideias de Suresh Canagarajah - um altamente conceituado professor e pesquisador da Penn State University, nos Estados Unidos da América sobre pesquisas e práticas translíngues. A fim de fazer a apresentação, uma entrevista com o autor foi planejada conjuntamente pelos professores Ruberval Franco Maciel (UEMS) e Cláudia Hilsdorf Rocha (UNICAMP). A entrevista foi conduzida em agosto de 2019, durante um evento realizado no Brasil. Levando-se em conta o extenso e crescente número de estudos sobre translingualismo no mundo todo nos últimos anos, bem como o papel preponderante de Canagarajah nesse campo, a realização da entrevista pretende ampliar visões relativas à literatura da área. A fim de situar e contextualizar as ideias do referido autor, algumas considerações sobre translinguagem como teoria linguística e abordagem educativa são inicialmente tecidas. Na sequência, o pensamento de Canagarajah é posto em diálogo com uma pluralidade de ideias, com o propósito de enfatizar a natureza complexa, dinâmica e desafiadora da virada translíngue na atualidade e suas possíveis conexões com trabalhos desenvolvidos no Brasil. Por fim, é apontada a importância da continuidade de estudos futuros, também em sua interface com abordagens multimodais, multissensoriais e afetivas.

PALAVRAS-CHAVE: Pesquisa e prática translíngues; Translinguagem; Educação Linguística; Enfoque Multimodal; Abordagem multissensorial.

\section{BRIEF WORD ON TRANSLINGUALISM}

Multilingual theories and policies have been increasingly debated in the field of Applied Linguistics in times of globalization, mobility and super-diversity (VERTOVEC, 2007; BLOMMAERT; RAMPTON, 2011). As stated by Canagarajah (2017a), the Multilingual Turn (MAY, 2014) is believed to have started an important movement towards a paradigm shift in Applied Linguistics. For the past couple of decades, critical applied linguists have strongly questioned language-based issues related to neoliberal ideologies and centralizing and undemocratic discourses that circulate in the most diverse fields of social life (CHUN, 2017). Such a transformative movement has presented us with critique of monoglossic, structuralist and rationalist concepts that have commonly guided language theories and pedagogic practices for so many years (CANAGARAJAH, 2017a). 
Not without criticism (FLORES, 2013; KUBOTA, 2014, for example), the critical and multilingual scholarship has fought against monolingual ideologies and resisted authoritative discourses and practices which attempt to silence cultural diversity and language heterogeneity. From this perspective, multilingual scholars have critically tried to propose "more ethical and inclusive language competencies, dispositions and practices" (CANAGARAJAH, 2017a, p. 2).

As an alternative to hegemonic language ideologies, other proposals, such as the translanguaging studies (GARCÍA; LI WEI, 2014; LI WEI, 2018; CANAGARAJAH, 2013; 2017a/b) have considered the expansion of linguistic and educational policies and practices, which could potentially challenge authoritative discourses and normative epistemologies. Such an approach can likewise contribute to question oppressive, monoglossic and monolithic views on language and culture in many different fields of knowledge, besides language education.

It seems fair to point out that, on the one hand, translanguaging research visibility has increased significantly these days, but, on the other hand, studies on what we understand as translanguaging today cannot be considered new, since its Welsh origins date back to the 90's (LI WEI; GARCÍA, 2016). Canagarajah (2013) has argued that these practices are also premodern, as in his heritage Tamil practice of manipralava style. As part of the Multilingual Turn movement, translanguaging emerged to refer to the dynamic nature of bilingualism and to the fuzzy boundaries which constituted the language repertoire of bilingual speakers (GARCÍA, 2009). From a translanguaging point of view, language is seen as a verb rather than a noun (GARCÍA; LI WEI, 2014), and the notion of translanguaging spaces (LI WEI, 2011; GARCÍA; LI WEI, 2014) emerges as an attempt to bridge "the artificial ideological divides between the so-called sociocultural and cognitive approaches" (LI WEI, 2018, p. 9). Translanguaging spaces can be therefore understood as complex, dynamic, creative and critical language practices which involve bi/multilingual speakers in social and historically bounded contexts.

According to Li Wei (2018, p. 10), translanguaging can be seen as a "practical theory of language", which challenges monolithic and monolingual orientations. As a consequence, translanguaging lenses leads both to a distinction between national languages as social constructions of nation-states and the complex language practices of 
bi/multilinguals (LI WEI; GARCÍA, 2016), and to an emphasis on multimodal and multisensory nature of language practices in contemporary society (LI WEI, 2018).

In his turn, Canagarajah $(2013 ; 2017 \mathrm{a} / \mathrm{b})$ highlights the practice-based nature of translanguaging by referring to it as translingual practice. Li Wei (2018, p. 18) resonates with Canagarajah's ideas (CANAGARAJAH, 2013), when stating that translanguaging involves a couple of fundamental premises, as follows:

Multilinguals do not think unilingually in a politically named linguistic entity, even when they are in a 'monolingual mode' and producing one namable language only for a specific stretch of speech or text. Human beings think beyond language, and thinking requires the use of a variety of cognitive, semiotic, and modal resources of which language in its conventional sense of speech and writing is only one. (LI WEI, 2018, p. $18)$.

As a theory of language, translanguaging can show its contributions by making "visible the complexity of language exchanges among people with different histories and releases histories and understandings that had been buried within fixed language identities constrained by nation-states" (LI WEI; GARCÍA, 2016, p. 5). As Blackledge and Creese (2014) point out, the translanguaging approach brings to light the social, historical, and political aspects that shape heteroglossic language practices in the contemporary world, emphasizing both their discursive and ideological constitution.

From an educational perspective, translanguaging has to do with the development of metacognitive and metalinguistic awareness and the promotion of "flexible instructional arrangements that leverage all the features of the language repertoire of bilingual students", so that they can "improve their academic engagement and outcomes", as well as develop "their bilingualism and biliteracy" (LI WEI; GARCÍA, 2016, p. 2). Resonating with García (2009) and Creese and Blackledge (2015), Li Wei (2018, p. 15) states that translanguaging is a very effective pedagogical practice, since it "empowers both the learner and the teacher, transforms the power relations, and focuses on the process of teaching and learning on making meaning, enhancing experience, and developing identity".

As a result, translanguaging, both as a language theory and an educational practice, can be seen as a highly transgressive orientation, once it challenges authoritative 
ideologies, resist inequalities and opens paths for other identitary, sociocultural and linguistic realities (LI WEI; GARCÍA, 2016). In this regard, Canagarajah (2017a) discuss translingual practices in their interface with neoliberal discourses. In short, he claims that neoliberal ideologies can appropriate a reductive form of multilingualism, which should be questioned so that translingualism could emerge in its more expansive form and, therefore, reveal its post-colonial potential. Echoing such ideas, Lee (2017) supports a more political approach to translanguaging and claims that such an orientation can highlight the translingual potential to make peripheric epistemologies and voices more visible and, this way, to highlight the importance for us to promote and engage in more egalitarian language (and educational) practices.

For Canagarajah $(2013 ; 2017 \mathrm{a} / \mathrm{b})$, translingualism is a strategic practice that can promote empowerment both as far as identitary and linguistic factors are concerned. In their turn, Canagarajah and Dovchin (2019) aim at expanding views on the transgressive nature of translanguaging by looking deeper into its political aspect. These authors discuss linguistic resistance in everyday life by investigating young people from different geographical contexts and the social media translingual practices in which they engage.

Li Wei and Zhu Ha (2013) discuss translanguaging from such a transgressive approach and emphasize that the prefix -trans involves a transdisciplinary orientation, the crossing of modes, languages and contexts and a transformative approach. Canagarajah (2017b) echoes many scholars (BLOCK; GRAY, HOLBOROW, 2012; BLOMMAERT, 2013; LI WEI; ZHU HA, 2013; PENNYCOOK; OTSUJ, 2015, just to mention a few) and broadens views on these matters by moving beyond structuralist orientations when debating translingual theories on language. He aligns translingual practices with spatial repertoires and claims that a translingual approach should involve four interrelated domains, which expand its definition.

From this point of view (CANAGARAJAH, 2017b), translanguaging has firstly to do with the idea of transcending autonomous languages. Besides, the focus can be broadened so as to include the need of transcending verbal resources in order to involve other semiotic resources and modalities in the meaning making process. Thirdly, it is important to expand on the notion of context, by transcending the text/context distinction and highlighting how a wide range of other semiotic features, previously relegated to 
spatiotemporal context, plays a crucial role as far as communication is concerned. Lastly, the transformative nature of translingual practice should be emphasized, so that its expansive and transgressive facet could be made more visible. Pennycook (2017) echoes such an expanding view on translanguaging by interconnecting it with the concepts of spatial repertoires and semiotic assemblages. Likewise, Blackledge and Creese (2017) call for a focus on the body as a dimension of the semiotic repertoire when discussing translanguaging and communicative interactions.

All in all, we can see that translanguaging is an expanding field and faces increasing challenges. In this regard, Li Wei (2018) states that the term has captured people's imagination, but there seems to remain many questions to be more deeply debated. In this author's own words:

The term translanguaging seems to have captured people's imagination. It has been applied to pedagogy, everyday social interaction, cross-modal and multi- modal communication, linguistic landscape, visual arts, music, and transgender discourse. The growing body of work gives the impression that any practice that is slightly non-conventional could be described in terms of translanguaging. There is considerable confusion as to whether Translanguaging could be an all-encompassing term for diverse multilingual and multimodal practices, replacing terms such as code-switching, code-mixing, code-meshing, and crossing. It also seems to be in competition with other terms, for example polylanguaging, polylingual languaging, multilanguaging, heteroglossia, hybrid language practices, translingual practice, flexible bilingualism, and metrolingualism, for academic discourse space. Dissents exist that question the need for the term, and indeed the other terms as well, dismissing it as merely a popularist neologism and part of the sloganization of the post-modern, possibly also post-truth, era. (LI WEI, 2018, p. 9).

Besides investigating translanguaging as an educative practice (CANAGARAJAH, 2013; GARCÍA; LI WEI, 2014; GARCÍA; JOHNSON; SELTZER, 2018; YIP; GARCÍA, 2018; and so on), many scholars have developed work on a large variety of issues from a translingual approach, among which we can mention studies on Sign language and the Deaf community (GARCÍA; COLE, 2016; MOULDER et. al., 2019); multimodality and translanguaging ethnographies (SHERRIS; ADAMI, 2019); translation (BAYNHAM; LEE, 2019); literature and art (LEE, 2015); translanguaging as a decolonial practice (MAKALELA, 2015; VERONELLI, 2016), just to mention a few. 
Given this, our purpose with planning, having and presenting the interview with Canagarajah, is to keep the debate alive and to open room for more issues that can enrich and expand views on translanguaging both abroad and here in Brazil.

Before doing so, it seems interesting to situate the activity by contextualizing our interest in the subject and offer some more details on what made this dialogue possible.

\section{INTERCONNECTING REPERTOIRES AND PATHS}

Our interest in translanguaging started as a result of the work we had been doing together, which involved the debate and the investigation on language education in Brazil from a transgressive point of view (ROCHA; MACIEL 2015a). Based on the literature available in the field, our focus expanded from such discussions, to include reflections upon the possible connections between a discursive approach to language and a translingual orientation (ROCHA; MACIEL, 2015b). Canagarajah's work is crucial to a better understanding about translingualism and to a more transformative and transgressive view on language practices these days.

Our first contact with Canagarajah was made possible by his online participation as a keynote speaker in an event held at the University of Campinas (UNICAMP) in 2014. After that, we kept in close touch with his upcoming publications and also maintained contact in order to discuss translingual practice in Latin American educational contexts from a transgressive perspective. His subsequent visits to speak and teach in different regions of Brazil provided us with additional opportunities to share ideas.

In more recent work (ROCHA; MACIEL, 2019), we draw upon Canagarajah's theories (CANAGARAJAH, 2017b) and expand our attention to translanguaging and the process of meaning making from a multimodal and multisensory point of view (MILLS, 2016), highlighting the role of affect in language practices (MASSUMI, 2015). We have also worked separately to discuss the decolonial potential of the translingual approach (ROCHA, 2019a/b; MACIEL; FERRARI, 2019) and the interconnection of translanguaging and its impacts on the health field (BARBOSA; MACIEL, 2019; PEREIRA; MACIEL, 2019).

Due to Canagarajah's invaluable contribution to the translanguaging scholarship, we believe that his ideas can offer great support to deepen and broaden the debate about 
translingual practice in Brazilian educational scenarios and also worldwide. We also think that his present views can help to highlight the political and transgressive roles of translanguaging studies in dialogue with Global South researchers. Consequently, both of us - Ruberval Maciel and Cláudia Rocha - carefully planned possible questions to be made to Canagarajah, who kindly accepted to give the interview. Canagarajah was eventually interviewed by Ruberval Maciel, who arranged the meeting during an event in Brazil, in 2019.

\section{CANAGARAJAH'S VIEWS ON TRANSLINGUAL PRACTICE: THE INTERVIEWEE AND THE INTERVIEW IN FOCUS}

\section{Face to face with Suresh Canagarajah}

\section{Ruberval Maciel:}

Cláudia and I have been working together on translanguaging theories and practices for quite a long time now. We have also kept in touch with you so that we could find support to more consistently discuss translanguaging in Brazilian scenarios. With this in mind, we planned this interview as a way to hear your ideas on issues that can be considered currently challenging in this field. For instance, discussions on translanguaging theory have emphasized the dynamic and fluid nature of language. Professor Suresh, let's start by the notion of language, how do you define language?

\section{Suresh Canagarajah:}

Right. That's a big question. I think traditionally we thought of language as having a life of its own. And that languages like English, Chinese, Portuguese have a separate identity. But we are beginning to now realize that at the bottom line of every language, there are only fluid resources. I mean, as Jan Blommaert said [...] we should start with the understanding of mobile resources rather than in immobile languages. That is, these are words and also other semiotic resources that help us in communication; and they travel, you know; these are sets of words that might be taken from another community and they might get appropriated, you know, in a different environment. So, these words are flowing freely and they are changing all the time, but what makes them a named language is a social and historical process over a period of time when people start using a set of words 
consistently with the indexicality that is very stable. And then people start attaching labels- like this corpus of words constitutes "Portuguese," or this corpus of words constitutes "English". But if you look at it this way, then we should be open to languages always changing. The traditional way of assuming there is a structure of language is too static and also very hegemonic in the sense we can't change anything. So, I do believe languages have form and develop identities and indexicalities, but it is a bottom up process. As Blommaert said, mobile semiotic resources get identified over time as named languages.

\section{Ruberval Maciel:}

And one of the things you have addressed very much in your papers is the differentiation of the monolingual orientation and the translingual orientation. So, what is the main importance of the two concepts, for example, in language teaching and the concept of language in general?

\section{Suresh Canagarajah:}

Right, as far as I'm concerned, I'm sure there are a lot of people thinking about pedagogical implications in different ways. But the monolingual orientation made us assume that learning a language was normative, you know that each language has a grammar and also that learning language means working within that particular language like English, and not with other languages that maybe your first language or other languages that is part of your repertoire. Because traditionally, we said they interfere with your learning of a new language. But the translingual approach would say that we cannot separate the languages that are part of one's repertoire. They have implications for the new language. What we learn has implications for our existing languages. We have to focus on how we develop the competence for all the languages we have in our repertoires. So, I guess teachers have to realize that the repertoires of students need to be respected, developed, rather than suppressed. In the traditional orientation, we sometimes try to keep away the languages students brought with them and, certainly, for translingual orientation what this involves is one's ability to work with multiple languages. So, a lot of research shows that multilinguals are not worried about the norms of every language, but they are 
focused on the strategies of communication. So, they ask themselves: "How can I make myself intelligible to this other person? So what kind of resources can I use in practice? Gestures? Strategies like repetition? Clarification? Reformulation?"So, these kinds of strategies can be very helpful in translingual communication. I'm proposing that teachers should focus not only on the form, or the grammar and lexical items; they should also focus on strategies of interaction. How do we work with people from different languages in order to create intelligibility and comprehension?

\section{Ruberval Maciel:}

Two main terms [...] some authors use the term translanguaging and you use the term translingual practice. How do you define translingual practice?

\section{Suresh Canagarajah:}

I think all these words are getting closer to each other now. I wrote in my 2013 book that translanguaging as it was used by some scholars in bilingual education [...] was used in a cognitive way; that is, about how people shuttle languages in their cognitive competence. They used it as an alternative to Chomsky's idea of competence, along the lines of Vivian Cook's idea of multi competence. And when I used Translingual Practice, I'm putting a lot of emphasis on the social practices - what people accomplish in their communication. But as you know, Ofelia García and Lee Wei, in their2014 book, say that this comparison is not fully true. They are also concerned about practices. So, I don't think I would emphasize the differences because I think they are all concerned about the practices now. I'm also considering the implications for cognition, because the mind is real and I think cognition as distributed. It's not just only in one place but everywhere in the body. We are all moving in the same direction. I was reading an article recently on the plane while I was traveling here, and this person argued that translingual practice is of course cognitive practice related to social distributions, but translanguaging is going beyond words to include semiotic resources. But this interpretation is not fully true, because I think that translingual practice is interested in going beyond semiotic resources also. We are all moving closer together to look at translingual practice as involving socially situated interactions. We are looking at multiple languages that come together with implications 
for cognition and cognitive processing as well.

\section{Ruberval Maciel:}

One of the terms that you have also addressed is the notion of code-switching, codemeshing and translanguaging. In some of your work you use the concept of code-meshing, how is it opposed to the other term, for example, like code-switching?

\section{Suresh Canagarajah:}

Right, there are some differences. At least in terms of traditional understandings of codeswitching. Traditionally, if you look at some early books on bilingualism and multilingualism, I'm thinking of books by Suzanne Romaine and others, they define codeswitching as different from code-mixing, where they say that in code-switching you require multilingual, bilingual competence. They are saying in code-mixing, or borrowing, the other language's word becomes part of your language, so you don't need bilingual competence. Secondly, they say that in code-switching, when you switch to another language, there is rhetorical value that is added. There is something more you are saying beyond the denotational meaning. You are not saying the same meaning in two different languages. So, when you switch you are maybe drawing attention to something, or you are trying to give an emotional kind of weight to what you are saying, so there's a rhetorical contribution. Whereas in code-mixing if you use another language like say in your Portuguese, if you use the English word 'computer' you're not saying anything special; it's just maybe another word in Portuguese now. Or if you say 'taxi', you're not saying anything special, and that person doesn't have to know English in order to say taxi. So, there was a traditional distinction. But what I find is that, in a lot of cases, like in Ben Rampton's example of 'crossing', you don't have bilingual competence but there is rhetorical distinction. So, for example, if I talk in English, you helped me in something, and I say - “obrigado, Ruberval”, I don't know Portuguese, but I'm still saying something rhetorically significant. So, you see, in using the simple Portuguese words I'm trying to be friends with you or I'm trying to accommodate your identity. So, that's why I created code-meshing, because there is something different communicated from both code-mixing and code-switching. 
Having said that, there are a lot of code-switching scholars who also agree now that you don't need bilingual competence for code-switching, and that there are a lot of different kinds of mixing. For example, styling. An Indian student studying in London, he uses a Hindi word, although it's part of his heritage; he might use it with an accent to give the impression that this is how Indians speak. I don't know if you could call it code-switching, because it's his language. But there's something else going on. There's more going on. Rampton calls this styling. So that's why I like the word code-meshing to talk about alternation between languages which don't always require bilingual competence. A lot of people say, as Ian Blommaert says, that we all have truncated competence - bits and pieces of words from many languages. Also, a lot of people talk about receptive multilingualism - we all understand more languages than we can speak. If that is true, there are all kinds of new meshings that are taking place.

But one clarification is that I might have indicated earlier that code-switching is not part of translanguaging. But I'm beginning to feel that translanguaging can be an umbrella term and code-switching can be part of that. It's one form of translingual practice. For example, it might depend on the subject in question. For example, if I switch to English while I am speaking Tamil, for me, these are two different semiotic systems, two different language systems. For me it might be code-switching in the sense that I think of these as two systems. So, it's possible that, in some cases, the particular switches might be so distinct for the person and for other people that it might work like code-switching. So, therefore, I think it can be part of translanguaging.

I also refer to Jeff MacSwan, who wrote an article recently, where he acknowledges translanguaging, that we all have a continuum of repertoires. But at the same time, he says it's possible that some languages are grouped separately in this continuum to activate code-switching. I'm comfortable with his idea. I think it's possible that for some speakers, certain words might get identified with certain languages. But my only problem with him is that he makes it looks like all acts of switching are a form of code-switching. I think that there are some switches that go beyond separated systems, like from truncated competence. There is no one system to put it into. An example is my use of "obrigado" in 
this trip to Brazil. There are also some switches which work beyond the two systems to give a third meaning. So those things cannot be tied to one grammatical system or to the other, maybe for a third space. So, as an example, in Korea, they write "5my god" in shops. What it means is, 5 in Korean is $\mathrm{OH}$, so it's "Oh my God"; but at the same time, in order to understand it, you must not limit yourself either to English or to Korean. You must connect the Korean oh (5) to the English "Oh". And, also, it works multimodally because you have to voice the number $\mathrm{OH}$; you don't say "five my god". So, that expression for me, it looks like it's neither tied to Korean or English but to a third space. So, I agree a lot with Jeff MacSwan that there might be certain switches that belong to separate language complexes for the speaker; but it doesn't explain everything about translanguaging.

\section{Ruberval Maciel:}

Another question - how does translanguaging relate to language ideology and power in the present society?

\section{Suresh Canagarajah:}

I guess still monolingual ideology is powerful in a lot of places. If you look at Europe and America, there's a lot of pushback against diversity and people are becoming really very nationalistic. And, also, language is implicated in these things - that native speakers own the land and foreigners can't speak the language etcetera. Also, that they just have to learn their language if they want to live there. So monolingualism is still dominant. But one of the problems is not to think only about monolingualism as evil, because I think a lot of neoliberal organizations, business agencies [...], they are also promoting multilingualism. They feel that having a repertoire of languages is good for business. So, it's looking as if translingualism is also becoming a fashion in language ideology for some circles. I have published a couple of pieces to show that translingualism as we see, as a lot of critical scholars see it, with a transformative possibility is different from the way some business companies and institutions are using translingualism - in the sense that they are using translingualism for profit making purposes. They are not interested in translingualism as an ecological, holistic form of practice, because they are trying to use it, manipulate it, for 
a political or profit-making purpose. But critical scholars are saying that translingualism is a kind of resistant practice. That is, we use diverse languages for the interests of our communities, to use them ethically, for empowering outcomes, for all of us. So, I use the distinction reductive translingualism and expansive translingualism because I want to say that some people are using translingualism for profit making purposes and self-interest, and we should be careful not to fall into that ideological trap.

\section{Ruberval Maciel:}

And what is the impact of translanguaging theory in Applied Linguistics and Language Education?

\section{Suresh Canagarajah:}

I think there is a very slow beginning in the sense that the dominant approaches need to be first questioned. It takes a lot of effort to rethink a lot of the old practices. So, in some senses, there is still some resistance to translingualism. There are a lot of teachers who are uncomfortable or they tend to worry. More importantly, there are some people who don't want to change. I was speaking in an AAAL conference two years back with Li Wei and others, and we had a panel on translanguaging; and one person, a senior American scholar, got up and said "Ok, I see that you have a very interesting and important notion that you are developing, but how does it speak to my teaching? If it doesn't fit into my current teaching practice, I can't accept this". So, I just got up and said "You have to change your teaching!" so... because she was trying to keep her teaching and to fit translingualism into her teaching... It doesn't work that way... and it was kind of bad news for her, she doesn't want to change anything. She just wanted it to be included in what she's already doing. So, I guess it's going to be a bit slow... people are going to rethink some of their current practices... and the good news is: it's starting! I see more and more, a lot of teachers who are thinking about it... who are trying to make spaces for translanguaging. But I don't think of it as unusual in the sense that... some people make it look like... "because it's difficult, it won't work". But I think everything starts like that. Everything different is difficult and slow, in the beginning you have to rethink a lot of old practices and you have to... imagine new possibilities; but after a while it might become fairly common. So, I'm waiting to see 
the developments.

\section{Ruberval Maciel:}

Right, and what are the challenges, for example, faced by translanguaging approaches and research?

\section{Suresh Canagarajah:}

One of the things is to realize that we shouldn't boil down translanguaging into a convenient practice like a method or a recipe for something. It's unwise to think that way. I think there are still a lot of theoretical development starting, and one of them is of course posthumanism, or new materialism - the idea of thinking of communication as involving a lot of different semiotic resources but also including the ecological environment, objects, and material things. So, I think a lot of people now use the term "spatial repertoires", and these are interesting developments. John Gumperz a long time ago talked about "repertoires" of the speech communities. He didn't want to say that in England there was just one language; but there are different dialects. This was a good start. Then people like Betsy Rymes talked about "communicative repertoire", that is, it's not only words but also other semiotic resources. And then Brigitta Busch talked about "personal repertoires". The whole community's repertoire doesn't have to be my personal repertoire. What they mean for my communicative practice is something very specific. And, finally, we are thinking of spatial repertoire in the sense that it's not just what I bring but there are a lot of resources out there. In the language situation of a teacher, or as a banker, there are resources I need to work with; I don't necessarily bring all of them, but I can use them for my purpose. So that's just one example of a new development.

But all this is going to make research difficult [...] because we don't know exactly what's our unit of analysis, what we should be focusing on? To put it simply, now we say everything is connected ecologically. Where do we stop - or start? That's a real question and will be there for some time. The way I resolve it is a simple one. I say it depends on the story we want to tell, what do you want to study? So, depending on what you want to analyze, what's the story I want to tell, I focus on this, this and this. I mean, in some cases 
we might say there might be a critical moment in interaction that shows that we forgot something. Therefore, we can include that. We can say that in order to understand this interaction, we need to focus on something, a missing piece, and which is not here, not now - maybe happened many years ago. So, that helps us bring those semiotic resources into the picture.

So, what's the unit of analysis would be an important question; what resources do we focus on would be an important question, that is, words, objects or things, or visuals that might also be depending on what the situation is all about. Or what kind of communication the situation is all about? So, those are, there are a lot of new challenges coming up in research. I think that we should take the challenge because we don't want easy research. You know, it's always good to grapple with difficult questions, but it's hard to say how might we resolve all of these questions.

\section{Ruberval Maciel:}

And translanguaging has to do with the political aspect, right? And it has to do with meaning making. Some authors call - translanguaging as a transgressive practice. In this sense, I wonder if you could address the aspect of meaning making, because meaning making has been there for a long time in other theories, for example in multimodality. Since the communicative approach, we have talked about meaning making. So, how do you perceive meaning making in the translingual perspective?

\section{Suresh Canagarajah:}

Right, right.

\section{Ruberval Maciel:}

How different is it from those other approaches?

\section{Suresh Canagarajah:}

So, yeah, this is kind of a big question and h'm ... a couple of things to be said is, uh... one of the things is that meaning making is a social accomplishment. It's not about what I 
want to say, it's also how the other person negotiates it and takes it. So, I might use the word distributed practice; meaning making is becoming a distributed practice. It's not about me or the other person, it's about something in-between, how it emerges, which also makes meaning something, uh, always fluid, in the sense that you can't be sure, you can't be committed to one meaning. I can't say this is what I wanted to say and the other person didn't take it up [...] I would say that a new possibility emerges, a new meaning that neither of us anticipated; and that's a success, because you created something new.

The other thing is, we are also recognizing how material access shapes meaning; in the sense that, if one has only certain instruments, certain resources, it's going to shape the meanings particularly. This orientation is upsetting the whole idea of the individual as an agent; you know, we can't say anything we want. It's not as if we think about something and we can put it into words. But we are now willing to realize there are constraints as well, you know the environment, we need to work with that environment.

So, uh, there are a lot of things also to be said about making meaning across diversity, in the sense when other people don't share your language or don't share your norms and one of the things some rhetoric scholars say is it requires a new ethics. In the sense of willingness to collaborate with other people, willingness to be tolerant and patient. Earlier, we [as the listener] said: "unless the speaker makes himself clear, it's a communicative failure; and I'm not gonna help them. I'm here to let you tell me what you want". But what you find there is what I usually call a one-way street communication. But if communication is to work and meaning is to be made across diversity, it has to be twoway communication, in the sense that both people have to work together. So, there's a lot to be said about ethics. But eventually it raises the possibility that all these new repertoires might fail because of power; in the sense that if somebody doesn't want to negotiate, if somebody doesn't want to collaborate with you, then that person's norms become dominant. But then, I would say, even domination or exclusion is a communicative success, in the sense that this is what that interlocutor wants to convey in the interaction. So, I can't do anything about it. So, it's not a communicative failure, but a different kind of communication; where somebody refuses to collaborate with me. But it also brings up a 
problem because sometimes we make it appear in translingual communication that everything in this form of communication is very democratic. But it doesn't have to be, because ideally translingual communication - in order to be successful and for meaning to be made - would require a particular ethics and particular politics. But the ideal situation doesn't exist all the time; so, there are, in real life, there are situations of power. Somebody wants to impose their own meaning. I'm an optimist. I feel we can renegotiate, we should try to renegotiate, we should try to educate the community, but it will take some time.

\section{Ruberval Maciel:}

Some authors have adopted the concept of assemblage, whereas others have used sensorial meaning making process, for example. How do you see the new directions into these studies, what are the future directions?

\section{Suresh Canagarajah:}

Yeah, yeah. I think it's good and bad, some things are promising, but there are also new questions being asked. So, some of the good things are developing a more inclusive orientation and communication rather than looking at only words or individuals when we are looking at communication.

\section{Ruberval Maciel:}

The aspect of feeling, how can we represent this aspect, for example?

\section{Suresh Canagarajah:}

That's right. I would say that they also raise questions about meaning: what is meaning? We find there are a lot of meanings you can't put into words; things that affect you, things that affect your perception. Along those lines, there is a representation theory. We have focused so much on facts, knowledge, truths but not on processes, strategies, feelings effect. The latter are also important in life but we usually give them second place, not an important place. So, that is also becoming part of meaning, they are also meaning. That will be addressed in nonrepresentational thinking. Embodiment is also another thing; not 
to separate meaning from our bodies and our physical lives and social lives. Space would also come in with an ecological orientation. Look at how time and space shape language. Earlier we focused on the here and now for meaning making. Now we find that meaning making is not necessarily here and now. It can embed layers of other times and places. It's a new question and what we are seeing is that we are getting a richer understanding of meaning and richer understanding of meaning and communication.

One of the things that is also happening is, we are questioning the role of the individual. We are saying, there is no individual. The individual is made up of social networks, material networks, but then, the problem now is - if somebody does evil, somebody shoots up fifty people, can we blame one person? Or is that person going to say "there is no person here, I'm made up of so many material resources and identities"? [...] So, a lot of people are saying that in order to account for ethics, morality, politics, political agency, we need to blame somebody; but we can't, if we go in the direction of assemblage. We're going to just list a long list of things to blame. We need to bring those questions back in to new materialism. We also think those are important processes. Sometimes, when we expand the theoretical paradigms, we need to kind of reinterpret the somewhat traditional assumptions, such as individual agency. There are a lot of people who are now trying to account for human agency. Despite the assemblage maybe people are still responsible for something. The way I look at it is, I think that, I borrow this from Arjun Appadurai. He says: we may not be agents but mediants. That means we mediate a lot of things and we all mediate differently. Like you, as an ethical person will mediate all these results in one way, and somebody who is unethical is going to mediate it in different ways, with different outcomes. So that might be a good starting point, to say, we are shaped by so many things but that doesn't mean there's only one way in which to act. The term I sometimes use is positioning. Like, with all these resources, I position myself in one way, another person will position himself in another way. That for me is a sign of also agency, that is, you are doing something to deal with all these resources in a particular ethical way or not. So those questions we are going to resolve over time and, you know, it's a kind of work that has to be done as we go forward. 


\section{Ruberval Maciel:}

That was a very good talk. Thank you for your time and hope to have another kind of conversation with you.

\section{Suresh Canagarajah:}

Yes, thank you very much, enjoyed talking.

\section{Ruberval Maciel:}

Thank you.

\section{MOVING FORWARD: BRIEF CONSIDERATIONS ON UPCOMING CHALLENGES AND POSSIBLE PATHS TO BUILD IN THE NEAR FUTURE}

Based on the discussions so far presented, as well as on Canagarajah's thoughts and current views on translingual research and practice, it seems fair to point out translingual theories and pedagogies are a thriving field. A translingual approach to language and language education is strongly committed to social justice and to the fight for more plural and non-hegemonic discourses, ideologies and practices. Bearing this in mind, it seems fair to say that there are many challenges to be faced in this area.

First of all, it is crucial to keep fighting neoliberal forces, so that translingualism can have its expansive and transgressive facet emerge (CANAGARAJAH, 2017a). Besides, it is likewise urgent to keep up the debate and research so that we can have a broader and deeper understanding as far as this paradigm shift of translanguaging is concerned (CANAGARAJAH, 2017b). It seems vital to keep more and more aligned with a spatial orientation to translanguaging, so that we succeed in treating "meaning making ability as distributed, accommodating the role of social networks, things, and bodies, beyond mind and grammar" and this way also favoring "strategic emplacement" (CANAGARAJAH, 2017b, p. 22).

Lastly, a very big challenge is related to dealing with translanguaging within educational scenarios which cannot be characterized as officially bi/multilingual. However, research on translanguaging in countries that tend to be considered monolingual, such as Brazil, has remarkably increased. This demand can be understood 
both as a result of increasing migratory flows experienced in such countries and as a consequence of a growing research interest in more open, dynamic and fluid perspectives for language studies.

In this regard, it is high time we started surveys of existing research, so that it would be possible to compile work on translanguaging (and corresponding terms) in Brazil. By means of such work, we believe that discussions on how Brazilian studies have perceived and addressed translanguaging in different research scenarios could be developed. We hope that the reflections in this paper can encourage more research in this field and inspire (Brazilian) scholars to keep adding to the existing translanguaging scholarship.

\section{REFERENCES}

BARBOSA, D. A.; MACIEL, R. F. Clampeando o cordão: a maternidade como espaço multissemiótico de construção de sentidos. Letras \& Letras. Uberlândia, v. 35, p. 28-52, 2019.

BAYNHAM, M.; LEE, T. K. Translation and translanguaging. London \& New York: Routledge, 2019.

BLACKLEDGE, A.; CREESE, A. Heteroglossia as practice and pedagogy. In: BLACKLEDGE, A.; CREESE, A. (Eds.). Heteroglossia as practice and pedagogy. New York/London: Routledge, p. 1-20, 2014.

BLACKLEDGE, A.; CREESE, A. Translanguaging and the body. International Journal of Multilingualism, v. 14, n. 3, p. 250-268, 2017. Available at: <https://doi.org/10.1080/ 14790718.2017.1315809>. Access on: 17 jul. 2018.

BLOCK, D.; GRAY, J.; HOLBOROW, M. Neoliberalism and applied linguistics. Abingdon: Routledge, 2012.

BLOMMAERT, J. Ethnography, superdiversity and linguistic landscapes: Chronicles of complexity. Bristol: Multilingual Matters, 2013.

BLOMMAERT, J.; RAMPTON, B. Language and superdiversity. Diversities, v.13, n.2, 2011. Available at: <http://www.unesco.org/shs/diversities/vol13/issue2/art1>. Access on: 17 jul. 2018.

CANAGARAJAH, S. Translingual Practice: Global Englishes and Cosmopolitan Relations. New York \& London: Routledge, 2013. 
CANAGARAJAH, S. Translingual practices and neoliberal policies: attitudes and strategies of African skilled migrants in Anglophone workplaces. New York: Springer, 2017a.

CANAGARAJAH, S. Translingual Practice as Spatial Repertoires: Expanding the Paradigm beyond Structuralist Orientations. Applied Linguistics, p. 1-25, 2017b. Available at: <https://doi.org/10.1093/applin/amx041. Access on: 10 nov. 2019.

CANAGARAJAH, S.; DOVCHIN, S. The everyday politics of translingualism as resistance practice. International Journal of Multilingualism, p. 1-18, 2019. Available at: $<$ https://doi.org/10.1080/14790718.2019.1575833>. Access on: 10 nov. 2019.

CHUN, C. W. The discourses of Capitalism: everyday economists and the production of common sense. New York: Routledge, 2017.

CREESE, A.; BLACKLEDGE, A. Translanguaging and identity in educational settings. Annual Review of Applied Linguistics, v. 35, p. 20-35, 2015.

FLORES, N. The unexamined relationship between neoliberalism and plurilingualism: A cautionary tale. TESOL Quarterly, v. 47, n. 3, p. 500-520, 2013.

GARCÍA, O. Bilingual education in the 21st century: A global perspective. Oxford: Wiley-Blackwell, 2009.

GARCÍA; O.; COLE, D. Lo que los sordos le enseñaron a los oyentes: desconstruyendo la lengua, el bilinguismo e la educación bilingue. ANAIS do Congresso internacional Seminário de educação bilíngue para surdos. Universidade do Estado da Bahia, Salvador (BA), Brasil, vol.1, p. 34-57, 2016.

GARCÍA, O.; FLORES, N.; WOODELY, H. Transgressing monolingualism and bilingual dualities: Translanguaging pedagogies. In: YIAKOUMETTI, A. (Ed.). Harnessing linguistic variation to improve education. Oxford, United Kingdom: Lang, p. 45-75, 2012.

GARCÍA, O.; JOHNSON, S.; SELTZER, K. The translanguaging classroom: leveraging student bilingualism for learning. Philadelphia: Caslon, 2017.

GARCÍA, O.; LI WEI. Translanguaging: language, bilingualism, and education. London: Palgrave Macmillan, 2014.

KUBOTA, R. The multi/plural turn, postcolonial theory, and neoliberal multiculturalism. Applied Linguistics, n. 33, p.1-22, 2014. Available at: <https://doi.org/10.1093/ applin/amu045> Access on: 10 jun. 2018.

LEE, J. W. The Politics of Translingualism: After Englishes. Nova York: Routledge, 2017. 
LEE, T. K. Translanguaging and visuality: Translingual practices in literary art. Applied Linguistics Review, v. 6, n. 4, p. 441-465, 2015. Avalilable at: <https://www.researchgate. net/publication/283892442>. Access on: 10 nov. 2019.

LI WEI. Moment analysis and translanguaging space: discursive construction of identities by multilingual Chinese youth in Britain. Journal of Pragmatics, n. 43, p.1222- 1235, 2011.

LI WEI. Translanguaging as a Practical Theory of Language. Applied Linguistics, v.39, n.1, p.9-30, 2018.

LI WEI; GARCÍA, O. From Researching Translanguaging to Translanguaging Research. In: K. King et al. (Eds.). Research Methods in Language and Education. Encyclopedia of Language and Education, p.1-14, 2016. Available at: <DOI 10.1007/978-3-319-023298_16-1>. Access on: 10 nov. 2019.

LI WEI; ZHU HA. Translanguaging Identities and Ideologies: Creating Transnational Space Through Flexible Multilingual Practices Amongst Chinese University Students in the UK. Applied Linguistics, v. 34, n. 5, p. 516-535, 2013.

LU, MIN-ZHAN; HORNER, B. Translingual literacy and matters of agency. In: CANAGARAJAH, S. Literacy as translingual practice: between communities and classrooms. London: Routledge, p. 26-35, 2013.

MACIEL, R. F.; FERRARI, L. F. D. N. Miradas situadas sobre translenguaje en una escuela en la frontera Brasil-Bolivia. Revista Raído, v. 13, n. 33, 2019.

MAKALELA, L. Translanguaging as a vehicle of epistemic access: cases for reading comprehension and multilingual interactions. Per Linguam, v. 31, n. 1, p. 15-29, 2015.

MASSUMI, B. Politics of affect. Cambridge: Polity Press. Kindle edition, 2015.

MAY, S. (Ed.). The multilingual turn: implications for SLA, TESOL and bilingual education. New York: Routledge, 2014.

MAZAK, C. M. Introduction: theorizing translanguaging practices in higher education. In: MAKAK, C. M.; CARROLL, K. S. (Eds.). Translanguaging in Higher Education: beyond monolingual ideologies. Bristol: Multilingual Matters, 2017, Kindle Edition.

MILLS, K. A. Literacy theories for the digital age: social, critical, multimodal, spatial, material and sensory lenses. New York: Multilingual Matters, 2016.

MOULDER, M. D.; KISTERS, A.; MORIARTY, E.; MURRAY, J. J. Describe, don't prescribe: the practice of translanguaging in the context of deaf signers. Journal of Multilingual and Multicultural Development, p. 892-906, 2019. Available at: <https:// doi.org/ 10.1080/01434632.2019.1592181>. Access on: 10 nov. 2019. 
OTSUJI, E.; PENNYCOOK, A. Metrolingualism: fixity, fluidity and language in flux. International Journal of Multilingualism, v. 7, n. 3, p. 240-254, 2010. Available at: $<$ https://www.researchgate.net/publication/249025313_Metrolingualism_Fixity_Fluidity_ and_Language_in_Flux>. Access on: 20 may. 2017.

PENNYCOOK, A. Translanguaging and semiotic resources. International Journal of Multilingualism, v. 14, n. 3, p. 269-282, 2017. Available at: <https://doi.org/ 10.1080/14790718.2017.1315810>. Access on: 15 jan. 2020.

PEREIRA, F. G.; MACIEL, R. F. M. Processos de construção de sentidos para além da dicotomia verbal e não verbal em contextos médicos. Revista Philologus. Rio de Janeiro, v.25, n.74, p. 2674-2681, 2019.

ROCHA, C. H. MOOCs em língua estrangeira: desafios para a construção de ecologias de aprendizagens situadas e transgressivas. In: FINARDI, K. (Org.). Transitando $e$ transpondo n(a) linguística aplicada. Campinas: Pontes Editores, p. 139-178, 2019a.

ROCHA, C. H. Language education in the fluidity of the burnout society: the decolonial potential of the translingual approach. D.E.L.T.A., v. 35, n. 4, p. 1-39, 2019b. Available at: <https://doi.org/ 10.1590/1678460x2019350403>. Access on: 15 jan. 2020.

ROCHA, C. H.; MACIEL, R. F. Língua estrangeira e formação cidadã: por entre discursos e práticas. Edição ampliada. Campinas: Pontes Editores, 2015a.

ROCHA, C. H.; MACIEL, R. F. Ensino de língua estrangeira como prática translíngue: articulações com teorias bakhtinianas. D.E.L.T.A., v. 31, n. 2, p. 411-445, 2015 b.

ROCHA, C. H.; MACIEL, R. F. Multimodalidade, letramentos e translinguagem: Diálogos para a educação linguística contemporânea. In: SANTOS, L.; MACIEL, R. (Orgs.). Formação e prática docente em língua portuguesa e literatura.Campinas: Pontes Editores, p. 117-144, 2019.

SHERRIS, A; ADAMI, E. (Eds.). Making Signs, Translanguaging Ethnographies: Exploring Urban, Rural and Educational Spaces. Bristol: Multilingual Matters, 2019.

VERONELLI, G. A. Sobre la colonialidad del lenguaje y el decir. Universitas Humanística, n. 81, p. 33-58, 2016. Available at: <http://dx.doi.org/ 10.11144/Javeriana.uh81.scdl> Access on: 21 jul. 2019.

VERTOVEC, S. Super-diversity and its implications. Ethnic and racial studies, v. 30, n. 6, p. 1024-1054, 2007.

YIP, J.; GARCÍA, O. Translinguagens: recomendações para educadores. Iberoamérica Social: revista-red de estudios sociales IX, p. 164-177, 2018. Available at: <https:// iberoamericasocial.com/translinguagens-recomendacoes-educadores/>. Access on: $21 \mathrm{jul}$. 2019. 
Recebido em: 19 fev. 2020.

Aceito em: 14 abr. 2020. 